\title{
レーザーブレイクダウンによる点音源を用いた微小空間の音響加振法*
}

\author{
細矢 直基 ${ }^{* 1}$, 永田 将希 ${ }^{* 2}$, 梶原 逸朗*3
}

\section{Acoustic Vibration Testing in a Micro-Space Based on a Point Source Generated by Laser-Induced Breakdown}

\author{
Naoki HOSOYA*1 ${ }^{*}$ Masaki NAGATA and Itsuro KAJIWARA \\ ${ }^{* 1}$ Department of Engineering Science and Mechanics, Shibaura Institute of Technology \\ Toyosu 3-7-5, Koto-ku, Tokyo, 135-8548 Japan
}

This paper proposes a method of acoustic vibration testing based on a point source generated by laser-induced breakdown in the air. A high-power Nd: YAG pulse laser is used in this system for generating the laser-induced breakdown in acoustic fields. Plasma formation can be realized by the laser-induced breakdown if the local intensity of the laser beam reaches $10^{15} \mathrm{~W} / \mathrm{m}^{2}$. The shock wave that is yielded by consuming a part of the plasma energy becomes a sound source. Assuming that the laser beam is focused to a small volume through a convex lens and the sound source by the laser induced-breakdown has nondirectional property, it is possible to create a point source with this technique. Securing the laser light path installs no device for acoustic excitation in acoustic fields. The system is validated by comparing the resonant frequencies of a micro-space measured by the laser-induced breakdown and calculated by theoretical model.

Key Words : Laser, Laser-Induced Breakdown, Non-Contact Excitation, Acoustic Vibration Testing, Plasma, Shock Wave, Sound and Acoustics, Point Source, Resonance

\section{1. 緒 論}

音響加振は，スピーカにより加振する方法が一般的であるが，スピーカが音場の特性に影響を及すことや，ス ピーカの形状や大きさにより空間に配置できないことなどがあるため，小型スピーカに関する検討がなされてい る(1). しかし，MEMS などの $\mu \mathrm{m}$ オーダーの微小空間内を対象とする場合は，小型スピーカでも対応が困難とな る. また，スピーカによる音響加振では，音源と参照点の距離がある程度離れていれば点音源とみなせるが，微 小空間内など音源と参照点が近距離の場合においては点音源とみなすことができない.

本論文では, レーザーブレイクダウン (Laser-induced breakdown: LIB) により理想的な点音源を任意の位置に生 成することで, 微小空間の音響加振を実現する. LIB とは, レーザービームを気体中に集光すると多光子過程に より原子・分子が複数の光子を吸収し電子を放出し, カスケード過程によりプラズマを形成させることをいう. このプラズマエネルギーの一部が消費されることで生成された衝撃波が，LIB による音源となる．LIB に関して

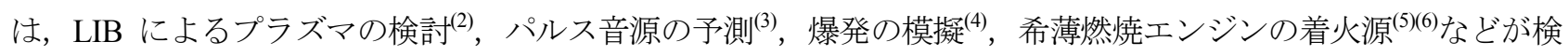
討されている. しかしながら, LIB を音響加振源として利用するための検討はなされていない. 水中における LIB による音源は，球面状に放射された無指向性音源であることが確認されている ${ }^{(7)}$. 空気中においても同様に無指 向性音源と考えることができ，レーザービームを凸レンズによりスポット半径を数十 $\mu \mathrm{m}$ 程度に集光しLIB を発 生させれば, 生成される音源は点音源となることが予想される. 本方法では, レーザーの光路さえ確保できれば,

\footnotetext{
* 原稿受付 2011 年 9 月 16 日

*1 正員, 芝浦工業大学 工学部（干135-8548 東京都江東区豊洲 3-7-5）

*2 学生員, 芝浦工業大学 大学院理工学研究科

*3 正員, 北海道大学 大学院工学研究院 ( $\bar{T} 060-8628$ 北海道札幌市北区北 13 条西 8 丁目)

E-mail: hosoya@sic.shibaura-it.ac.jp
} 
音源の位置に何らデバイスを設置することなく，音響加振が実現される．この理想的な点音源を微小空間内にお ける任意の位置に配置することができれば，音響加振の適用範囲拡大が期待できる.

本実験では, 高出力 $\mathrm{Nd}: \mathrm{YAG}$ パルスレーザーと凸レンズを組み合わせた音響加振システムを構築する. 凸レン ズによりレーザービームを集光することで，レーザービームのエネルギー密度を LIB の闇值である $10^{15} \mathrm{~W} / \mathrm{m}^{2}$ 以 上とする．まず，はじめに，LIB の閾值，集光されたレーザービームのスポット半径（以下，スポット半径と呼 ぶ), およびレーザーパルスエネルギーの間の関係を明らかにする. 次に, LIB による音源の音圧とスポット半径, レーザーパルスエネルギーの関係を明らかにした後，この音源が無指向性の点音源であることを示す．さらに， アルミニウムパイプ内を微小空間と想定し, 本手法および理論的に得られたこの微小空間の共鳴周波数を比較・ 評価し, 有効性を示す.

\section{LIB を用いた音響加振システムの構築}

LIB により生成された点音源を用いた音響加振システムについて述べる.

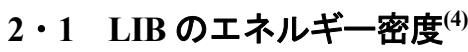

LIB に必要なエネルギー密度 $I\left[\mathrm{~W} / \mathrm{m}^{2}\right]$ について説明する。 $I$ は，レーザーパルスエネルギーを $E[\mathrm{~J}]$, パルスレー ザーの継続時間を $T[\mathrm{~s}]$, レーザーが照射される領域を $S\left[\mathrm{~m}^{2}\right]$ とすると式(1)のようになる.

$$
I=\frac{E}{S T}
$$

空気中における LIB の閾值は $I \geq 10^{15} \mathrm{~W} / \mathrm{m}^{2}$ である. この闇值に達しない場合は凸レンズによりレーザービーム を集光し，スポット半径を小さくすればよい.

\section{$2 \cdot 2$ LIB を用いた音響加振システム}

LIB による点音源を用いた音響加振システムを図 1 に示す. 本システムでは, Nd: YAG パルスレーザー

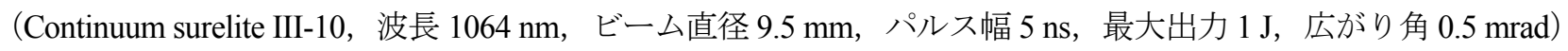
を用いた. また, LIBにより点音源を生成するため, 凸レンズを光学定盤上に設置しレーザービームを集光した.

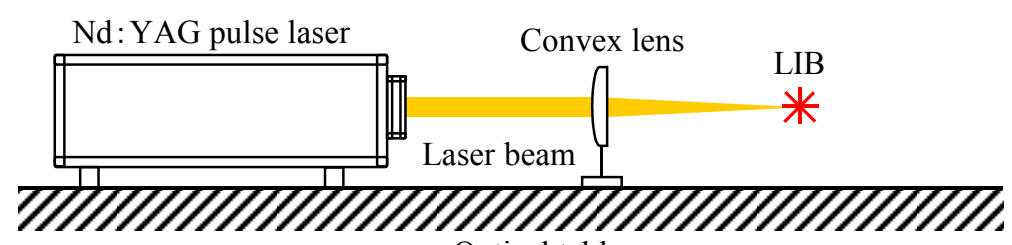

Optical table

Fig. 1 Acoustic excitation system by a point source generated by LIB.

\section{LIB の閾値}

LIB により点音源を生成するために, LIB の閾值とスポット半径（スポット面積），およびレーザーパルスエネ ルギーとの関係を明らかにする。

表 1 に示寸 3 種類の焦点距離 $100 \mathrm{~mm}$ (Lens L1), $200 \mathrm{~mm}$ (Lens L2), $300 \mathrm{~mm}$ (Lens L3)の凸レンズを用いること で，スポット半径を変化させ，実験的に LIB の閾値を調べる. また, 表 1 においては, スポット半径, スポット 面積も示しており，焦点距離が大きくなるにしたがいスポット半径も大きくなるため，LIB の閾值が変化するこ とがわかる．スポット半径 $r[\mathrm{~m}]$ は，凸レンズの焦点距離 $f[\mathrm{~m}]$, レーザービームの広がり角 $\Delta \theta[\mathrm{rad}]$ から得ること ができる( ${ }^{(8)}$.

$$
r=f \Delta \theta
$$


図 2 にLIB の閾值を測定するための実験装置概略図を示寸，光学定盤上にパルスレーザー，凸レンズ，パワー メーター（OPHIR 製，NOVA II）を配置した．LIBにおいては，全てのレーザーパルスエネルギーを消費するこ とはない(3). したがって，LIB の閾值は，出力されたレーザーパルスエネルギーと LIB により消費されなかった エネルギー（以下，残留エネルギーと呼ぶ）をパワーメーターで測定することで決定した. 本実験では，3 種類 の凸レンズに対して, レーザーパルスエネルギーを 69.2 990.9 mJ 間で変化させ, 残留エネルギーを測定した. 測定回数は 10 とし, その平均を測定值とした. パワーメーターは, ロレンズ通過後のスポット半径が集光前と同 様になる位置に配置した.

表 2 は，3 種類の凸レンズに対する LIB の閾值の測定結果を示しており，比較のため LIB が発生しないレーザ ーパルスエネルギー (69.2 mJ)，LIB の闇值 (Threshold), 最大レーザーパルスエネルギー (990.9 mJ) を示してい る. 表 2 を見ると，凸レンズの焦点距離により焦平面でのスポット半径が異なるため，LIB の閾值が変化してい ることがわかる，したがって，効率良くLIB を発生させるための条件として，凸レンズの焦点距離は短く，レー ザーパルスエネルギーは大きい方が適している，LIB が発生していない状態においても，凸レンズの透過損失や 表面での反射などによりレーザーパルスエネルギーは $10 \%$ 程度消費される. 本実験で LIB を発生させるためのレ 一ザーパルスエネルギーは，Lens L1 では $116.1 \mathrm{~mJ}$ 以上，Lens L2, L3 では共に $241.0 \mathrm{~mJ}$ 以上であることがわかっ た.

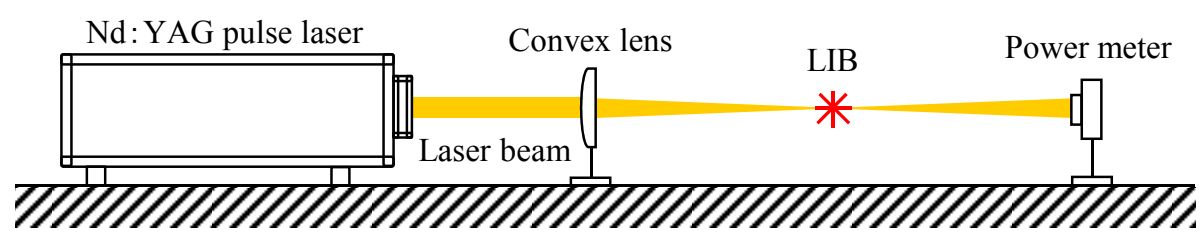

Optical table

Fig. 2 Experimental system for measuring consumption energy in LIB.

Table 1 Configurations of the three convex lenses used to focus the laser beam

\begin{tabular}{c|c|c|c}
\hline \hline Lens & Focal length $f[\mathrm{~mm}]$ & Spot radius $r[\mu \mathrm{m}]$ & Area $S\left[\mathrm{~mm}^{2}\right]$ \\
\hline Lens L1 (BK7 SLB-30-100P) & 100 & 25 & 0.0020 \\
Lens L2 (BK7 SLB-30-200P) & 200 & 50 & 0.0079 \\
Lens L3 (BK7 SLB-30-300P) & 300 & 75 & 0.0177 \\
\hline
\end{tabular}

Table 2 Laser pulse energy used by LIB as a function of spot radius for the three convex lenses

\begin{tabular}{c|c|c|c}
\hline \hline Lens & Laser pulse energy $E[\mathrm{~mJ}]$ & Residual energy [mJ] & Consumption ratio [\%] \\
\hline \multirow{4}{*}{ L1 } & 69.2 & 60.4 & 87.3 \\
& 116.1 (Threshold) & 78.1 & 67.3 \\
& 990.9 & 48.7 & 4.9 \\
\hline \multirow{4}{*}{ L2 } & 69.2 & 59.9 & 86.6 \\
& 241.0 (Threshold) & 135.5 & 56.2 \\
& 990.9 & 109.5 & 11.1 \\
\hline \multirow{3}{*}{ L3 } & 69.2 & 60.5 & 87.4 \\
& 241.0 (Threshold) & 152.9 & 63.4 \\
& 990.9 & 118.8 & 12.0 \\
\hline
\end{tabular}




\section{LIB による点音源の評価}

LIB により生成された点音源の音圧，および加振可能な周波数帯域を検討し，音響加振源としての有効性を示 す．また，この点音源の音圧とスポット半径，焦点深度，レーザーパルスエネルギーとの関係，および指向性を 調べる.

\section{$4 \cdot 1$ 音圧の測定方法}

図 3 に, LIB による点音源の音圧を測定するためのシステムを示す. 2 章, 3 章と同様に, 光学定盤上にパルス レーザー，凸レンズを配置した．また，本実験では，厚さ $40 \mathrm{~mm}$ の木材に厚さ $50 \mathrm{~mm}$ のグラスウールを貼付し て製作した簡易無響箱を光学定盤上に設置した．なお，この簡易無響箱は，本実験の測定周波数範囲内では有効 な音響特性であることを確認している，レーザーの照射光路を確保するため，簡易無響箱の一側面を開放して使 用した． LIB の発生位置は，簡易無響箱入り口から $100 \mathrm{~mm}$ とした．図 3 のように，簡易無響箱内にマイクロホ ン（リオン UC-54, 測定周波数範囲: $20 \mathrm{~Hz} \sim 100 \mathrm{kHz}$ ) を音源から $200 \mathrm{~mm}$ の位置に設置し, スペクトルアナライ ザ（A/D: NI PXI-5922，Software: キャテック CAT-System）により音圧の時刻歷波形，および音圧のスペクトルを 測定した. サンプリング周波数 $300 \mathrm{kHz}$ ，サンプリング点数は 65536 とした. 各条件での測定回数は 10 とした.

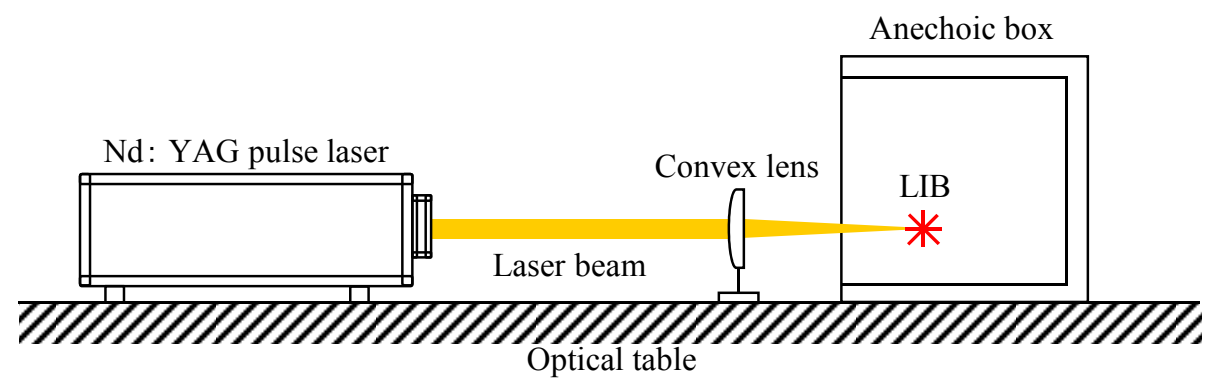

(a) Layout of optical system

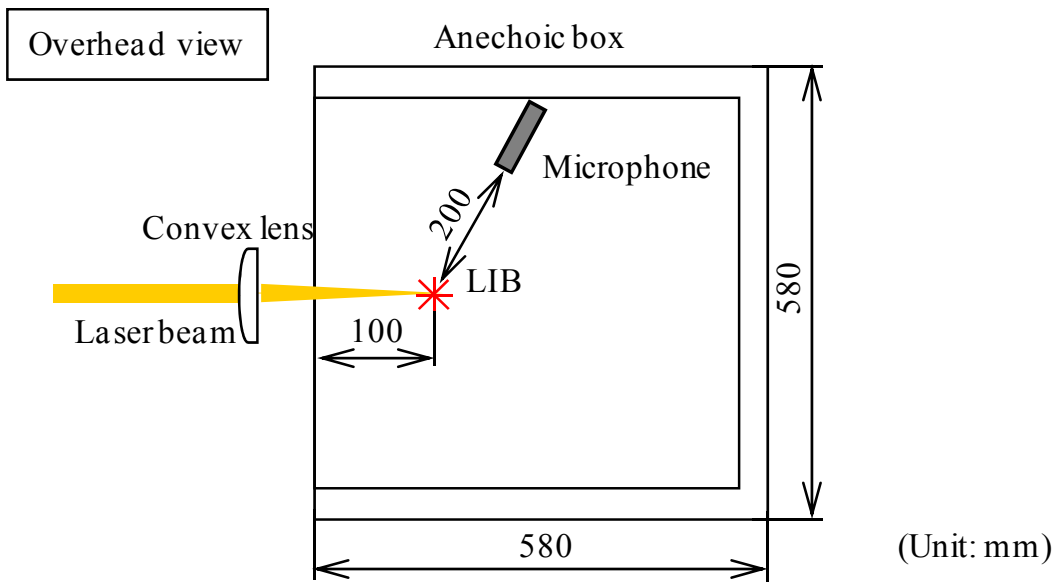

(b) Layout of microphone in the anechoic box (overhead view)

Fig. 3 Acoustic vibration testing system using a point source generated by LIB. 


\section{$4 \cdot 2$ 音圧とスポット半径の関係}

スポット半径を変化させた際の LIB による点音源の音圧，再現性，周波数特性を調べる．本実験では，表 1 に 示した 3 種類の焦点距離の凸レンズを用いた。 また，レーザーパルスエネルギーは $335.9 \mathrm{~mJ}$ (Energy E1)とした. 図 4 に，LIB による点音源の音圧の時刻歴波形において音圧発生付近の時間軸を拡大した図を示す.これらの時

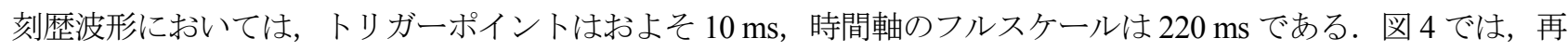
現性を確認するために 10 回測定した音圧を重ねて示している.また, 音圧の最大值の平均をそれぞれ示している. 図 5 は，図4 に対応するパワースペクトルの平均值を示している，図4 を見ると，LIBにより生成された点音源 はパルス幅の短い（パルス幅 $20 \mu \mathrm{s} ）$ ほぼ理想的なインパルスであり, 高い再現性を有していることがわかる.ま た, スポット半径により音圧の大きさが変化するが, パルス幅はほぼ同一であることが確認できる. 図 5 より LIB による点音源は，高周波数帯域までほぼ一様な音響加振成分を有するインパスル状の波形であるが，パワースペ クトルの大きさが若干変化している，これは，簡易無響箱を一側面開放して測定したことやマイクロホンの特性 などによる影響と考えられる．したがって，LIB の発生位置においては，理想的なインパルス波形である点音源 と予想される.

\section{$4 \cdot 3$ 音圧とレーザーパルスエネルギーの関係}

LIB による点音源の音圧とレーザーパルスエネルギーの関係を調ベる.レーザーパルスエネルギーは, $335.9 \mathrm{~mJ}$ (Energy E1), 798.2 mJ (Energy E2), 990.9 mJ (Energy E3)の 3 種類で行った. 凸レンズの焦点距離を 300mm（スポ ット半径 $75 \mu \mathrm{m}$ ) (Lens L3) とした. 図 6 に, LIBによる点音源の音圧の時刻歴波形を示寸．図 6 では, 10 回測定 した音圧を重ねて示している，また，音圧の最大值の平均をそれぞれ示している．図７は，図 6 に対応するパワ ースペクトルの平均值を示している. 図 6 より, レーザーパルスエネルギーの増加に伴い, LIB による点音源の 音圧は大きくなるが，再現性は低下しばらつきが観察される。これは，レーザーパルスエネルギーが大きくなる と, 凸レンズでレーザービームを集光する際，レーザービームのエネルギー密度が焦平面の手前で闇值に達し， LIB が発生したことで，LIB の発生位置がわずかに変化することが原因として考えられる. したがって, 焦点距 離が長い凸レンズほど, LIB 発生位置の誤差は大きくなる傾向にある. 図 8 は, レーザーパルスエネルギーを 990.9 $\mathrm{mJ}$ (Energy E3), 凸レンズの焦点距離を $100 \mathrm{~mm}$ (スポット半径 $25 \mu \mathrm{m}$ ） (Lens L1)とした際の LIBによる点音源の 音圧の時刻歴波形を示しており，図 6(c)に対応する. 図 6(c) と図 8 を比較すると, 凸レンズの焦点距離を短くす ることで，スポット半径，および焦点深度が小さくなり，LIB による点音源の再現性が向上寸ることがわかる. 


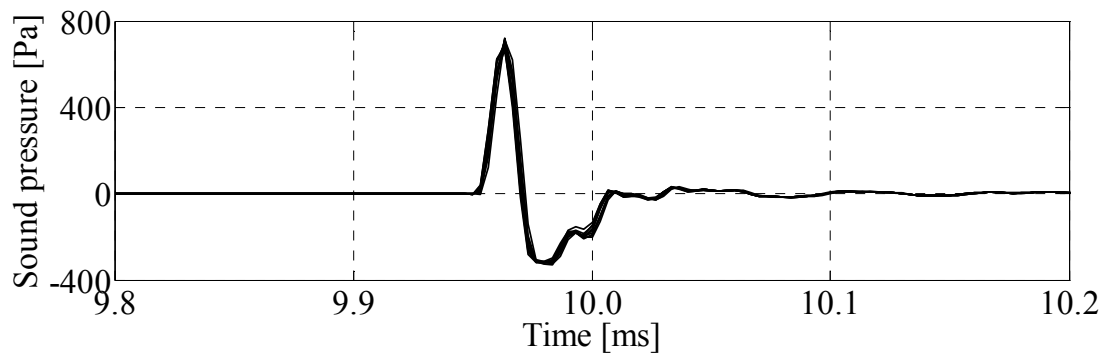

(a) Convex lens L1 ( $f=100 \mathrm{~mm}$ ) (average of peak sound pressure: $698.9 \mathrm{~Pa}$ )

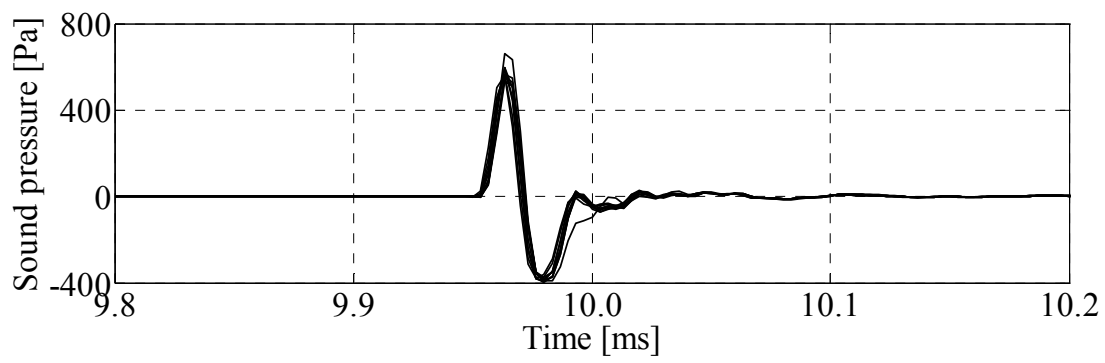

(b) Convex lens L2 ( $f=200 \mathrm{~mm}$ ) (average of peak sound pressure: $577.1 \mathrm{~Pa}$ )

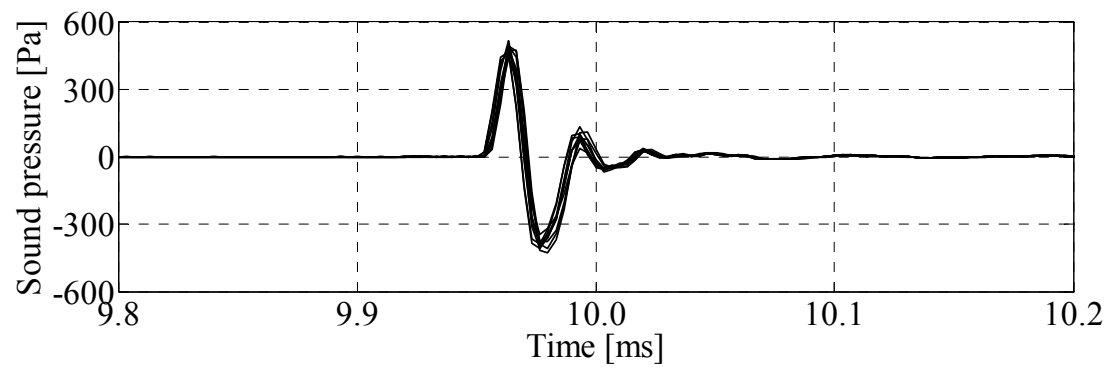

(c) Convex lens L3 ( $f=300 \mathrm{~mm}$ ) (average of peak sound pressure: $480.3 \mathrm{~Pa}$ )

Fig. 4 Time responses of sound pressure generated by LIB (energy E1 $(E=335.9 \mathrm{~mJ})$ ).

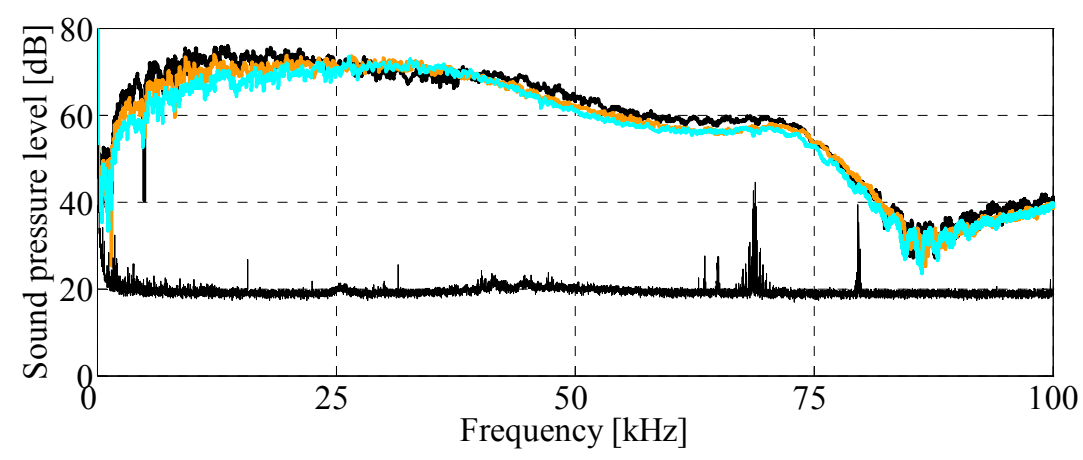

—: Lens L1 - : Lens L2 - : Lens L3 - : Background noise

Fig. 5 Power spectra of sound pressure generated by LIB for three convex lenses. 


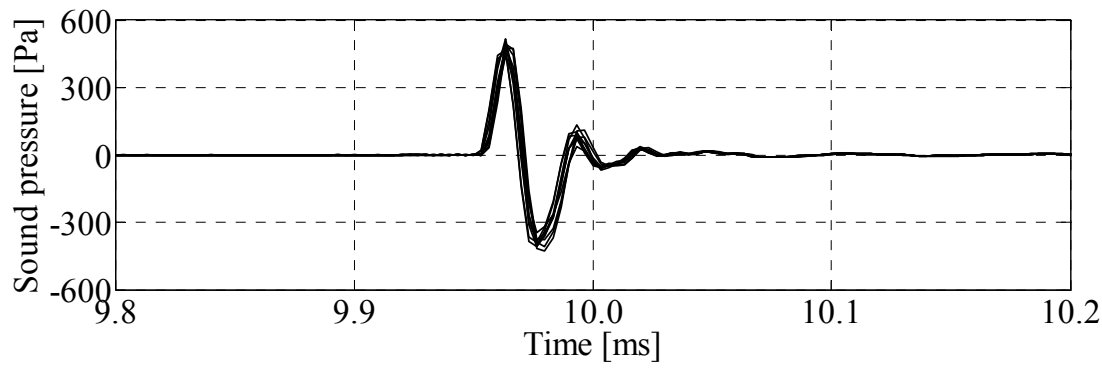

(a) Laser pulse energy E1 $(E=335.9 \mathrm{~mJ})$ (average of peak sound pressure: $480.3 \mathrm{~Pa}$ )

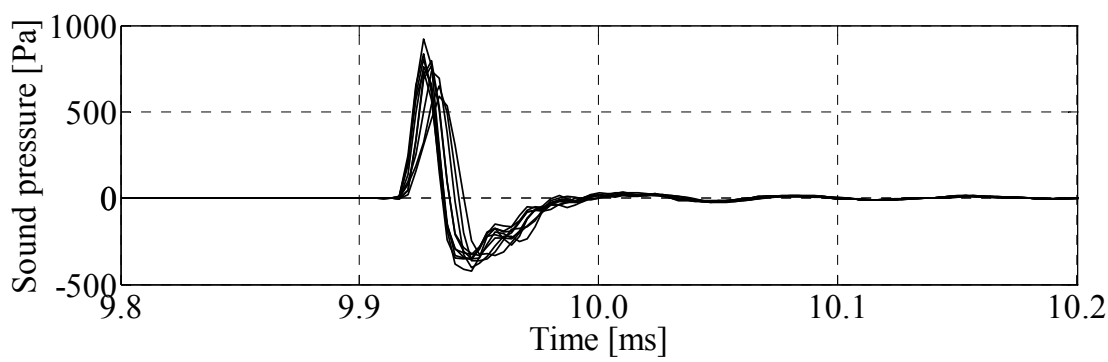

(b) Laser pulse energy E2 $(E=798.2 \mathrm{~mJ})$ (average of peak sound pressure: $759.7 \mathrm{~Pa}$ )

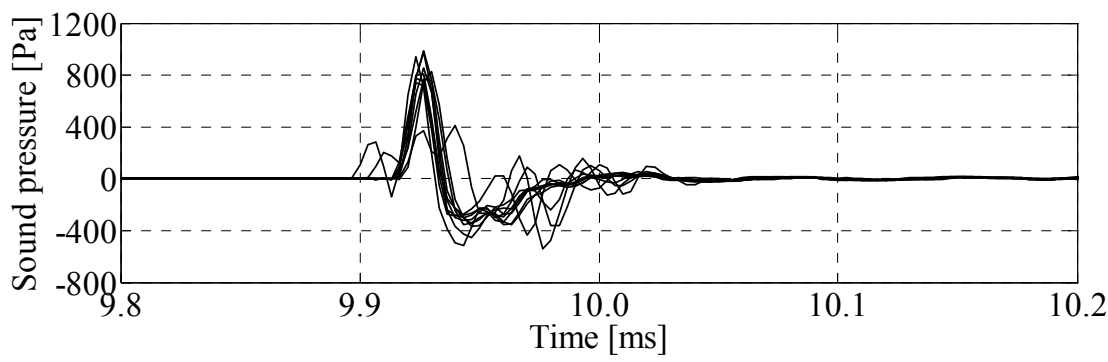

(c) Laser pulse energy E3 $(E=990.9 \mathrm{~mJ})$ (average of peak sound pressure: $808.7 \mathrm{~Pa}$ )

Fig. 6 Time responses of sound pressure generated by LIB (lens L3 $(f=300 \mathrm{~mm}))$

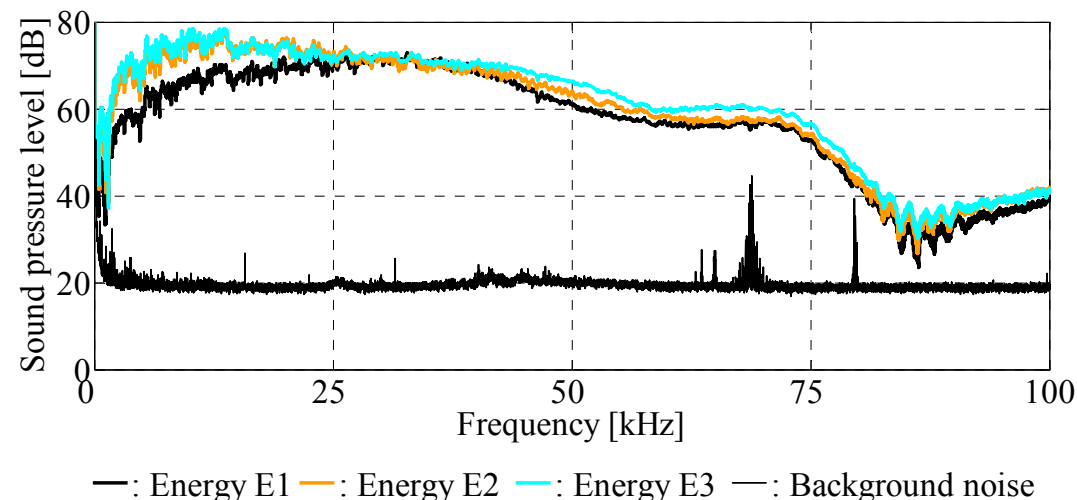

Fig. 7 Power spectra of sound pressure generated by LIB for three laser pulse energies. 


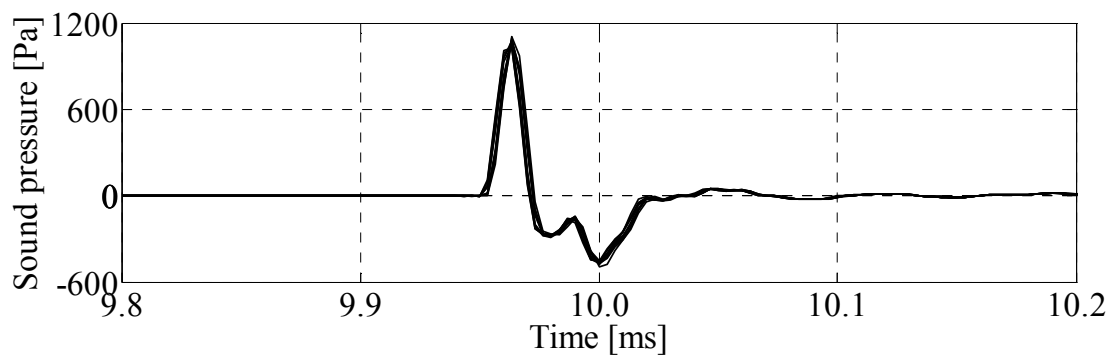

Fig. 8 Time responses of sound pressure generated by LIB (lens L1 $(f=100 \mathrm{~mm})$, energy E3 $(E=990.9 \mathrm{~mJ})$ ).

\section{$4 \cdot 4$ 指向性}

LIB により生成された点音源が無指向性であることを検証する．図 9 に示すように，簡易無響箱内に LIB によ る点音源を生成し，その音源から $80 \mathrm{~mm}$ 離れた 12 箇所にマイクロホンを設置し，音圧を測定した。レーザーパ ルスエネルギーを $197.4 \mathrm{~mJ}$ ，凸レンズの焦点距離を $100 \mathrm{~mm}$ （スポット半径 $25 \mu \mathrm{m} ）$ (Lens L1)とした.

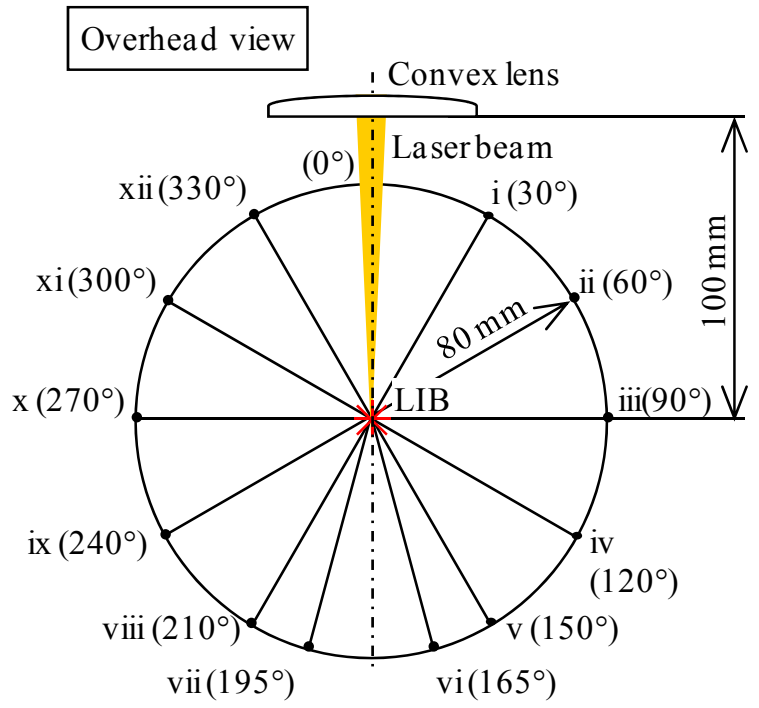

Fig. 9 Layout of microphone in the anechoic box for directional test (overhead view)

図 10 に，各点で測定された音圧のパワースペクトルの平均值を重ねて示す。また，表 3 に， $10,30,50,70 \mathrm{kHz}$ のそれぞれの周波数における各点での音圧レベルを示す．簡易無響箱内において対称な測定点（例えば，測定点 i, xii）における音圧の時刻歴波形，およびそのパワースペクトルを比較したところ，両者はほぼ一致しているこ とを確認した. 図 10 を見ると, 全測定点における音圧のパワースペクトルは測定対象周波数範囲内で良く一致し ている.また，表 3 より，各周波数における音圧レベルの差はおよそ $4 \mathrm{~dB}$ であるが，これはマイクロホンによる 測定点の位置のずれ，LIB の発生位置のずれなどの影響が考えられる．したがって，音源と測定点の距離が同一 であれば，測定される音圧レベルはどの位置においてもほぼ同一であり，LIBにより生成された点音源は無指向 性であるといえる。 


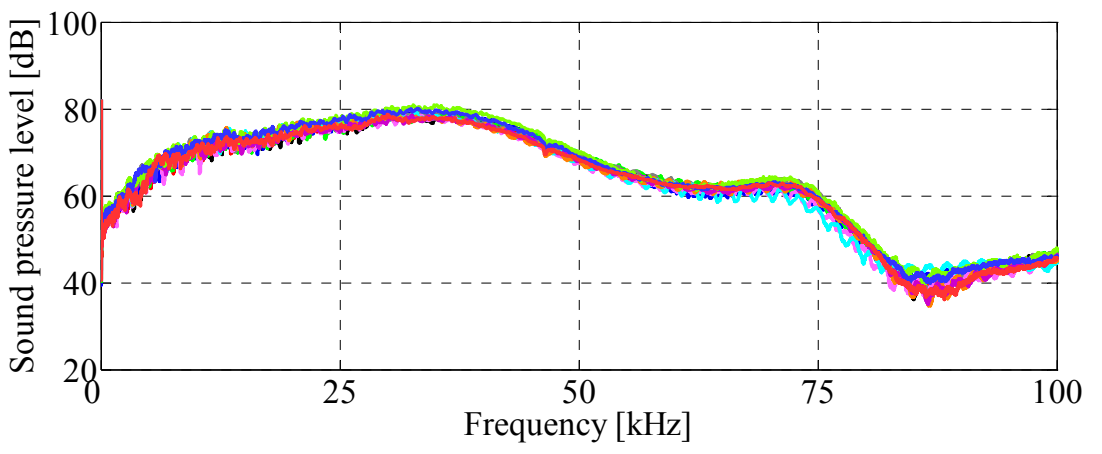

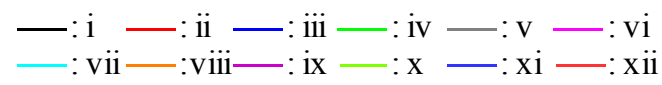

Fig. 10 Measured power spectra at each point.

Table 3 Sound pressure levels and measurement positions in each frequency

\begin{tabular}{c|c|c|c|c}
\hline \hline \multirow{2}{*}{$\begin{array}{c}\text { Measurement } \\
\text { positions }\end{array}$} & \multicolumn{4}{|c}{ Sound pressure level [dB] } \\
\cline { 2 - 5 } i & $70 \mathrm{kHz}$ & $30 \mathrm{kHz}$ & $50 \mathrm{kHz}$ & $70 \mathrm{kHz}$ \\
\hline ii & 69.5 & 78.0 & 69.0 & 62.5 \\
iii & 68.7 & 77.8 & 68.5 & 62.5 \\
iv & 71.7 & 78.0 & 69.4 & 61.1 \\
v & 70.9 & 78.2 & 69.4 & 61.7 \\
vi & 71.5 & 78.0 & 67.5 & 62.8 \\
vii & 72.2 & 77.9 & 68.2 & 60.2 \\
vii & 71.7 & 77.6 & 68.2 & 61.8 \\
ix & 70.7 & 77.0 & 67.9 & 61.8 \\
x & 72.4 & 80.0 & 70.0 & 63.9 \\
xi & 72.1 & 79.5 & 69.0 & 62.9 \\
xii & 71.1 & 78.6 & 68.3 & 62.9 \\
\hline
\end{tabular}

\section{LIB による点音源を用いた微小空間の音響加振}

スピーカの設置が困難であるアルミニウムパイプ内を微小空間と想定し，LIB による点音源を用いてこの空間 内の共鳴周波数を測定する.

\section{$5 \cdot 1$ アルミニウムパイプの共鳴周波数}

本実験で用いるアルミニウムパイプの共鳴周波数を求める. アルミニウムパイプの寸法は外径 $20 \mathrm{~mm}$, 内径 17 $\mathrm{mm}$, 全長 $300 \mathrm{~mm}$ とした．境界条件は両端開口であるため，開口端補正を考慮したアルミニウムパイプの長さは $310.2 \mathrm{~mm}$ となった. アルミニウムパイプの共鳴周波数 $f_{n}[\mathrm{~Hz}]$ は, モード次数 $n$, 音速 $c[\mathrm{~m} / \mathrm{s}]$, アルミニウムパイ プの長さ $L[\mathrm{~m}]$ とすると式(3)のようになる ${ }^{(9)}$.

$$
f_{n}=\frac{n c}{2 L}
$$


また，cは次式で得られる。

$$
c=\sqrt{\frac{\kappa R_{0} T}{M}}
$$

ここで，Kは比熱比， $M[\mathrm{~kg} / \mathrm{mol}]$ は気体の分子量， $R_{0}[\mathrm{~J} / \mathrm{mol} \mathrm{K}]$ は一般気体定数， $T[\mathrm{~K}]$ は温度である. 本実験は温度 $T=294.15 \mathrm{~K}$ の空気中で行ったため, $\kappa=1.403, M=28.966 \times 10^{-3} \mathrm{~kg} / \mathrm{mol}, R_{0}=8.314 \mathrm{~J} / \mathrm{mol} \mathrm{K}$ より,$c=344.2 \mathrm{~m} / \mathrm{s}$ と なった．これを踏まえ，式(3)よりアルミニウムパイプの共鳴周波数を計算したところ，表 4 に示すように $5 \mathrm{kHz}$ 以下の周波数範囲に 9 個の共鳴周波数が存在した.

\section{$5 \cdot 2$ 音響加振システム, および音響特性の測定方法}

LIB による点音源を用いた微小空間の共鳴周波数を測定するための音響加振システム，および音響特性の測定 方法について述べる. 図 11 に実験装置の概略図を示す. 4 章と同様に, 光学定盤上にパルスレーザー, 凸レンズ, 簡易無響箱を配置し，簡易無響箱内にアルミニウムパイプ，マイクロホンを設置した．マイクロホンとアルミニ ウムパイプの開口端との距離は $150 \mathrm{~mm}$ とした. 全長 $300 \mathrm{~mm}$ のアルミニウムパイプの任意の位置に LIB を発生 させることを可能にするために，凸レンズの焦点距離は $300 \mathrm{~mm}$ （スポット半径 $75 \mu \mathrm{m} ）$ (Lens L3), レーザーパ ルスエネルギーは $335.9 \mathrm{~mJ}$ (Energy E1)とした. 図 11 に示すように加振位置lは, レーザー照射側のアルミニウム パイプの開口端から 72.5 mm (Point 1), $25.9 \mathrm{~mm}$ (Point 2)の 2 種類とした. Point 1 は 4 次モードの節，Point 2 は 1 9 次モードを全て励起できる位置である. 測定条件は, サンプリング周波数 $50 \mathrm{kHz}$, サンプリング点数は 65536, 測定における平均化回数は 10 とした. 出力はスペクトルアナライザ (4 章と同様) により記録した. LIB 発生後 の消費されなかったレーザーパルスエネルギーは，ビームディフューザーにより拡散させた．

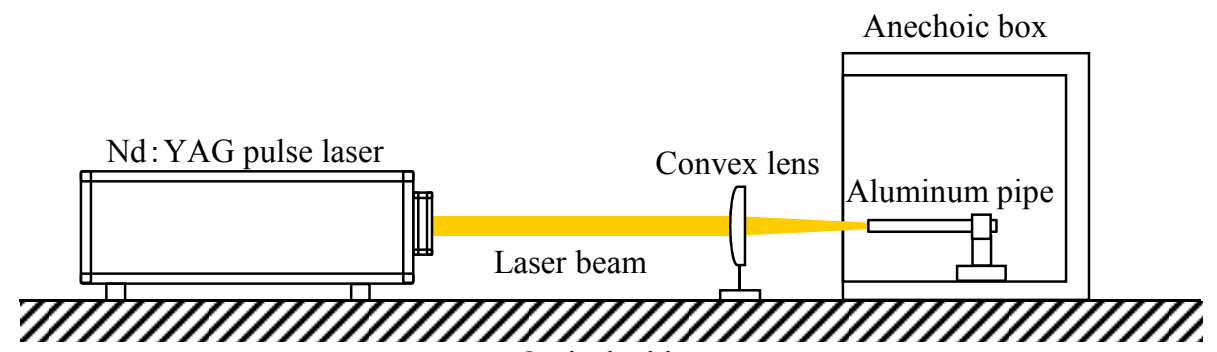

Optical table

(a) Experimental system by acoustic vibration testing

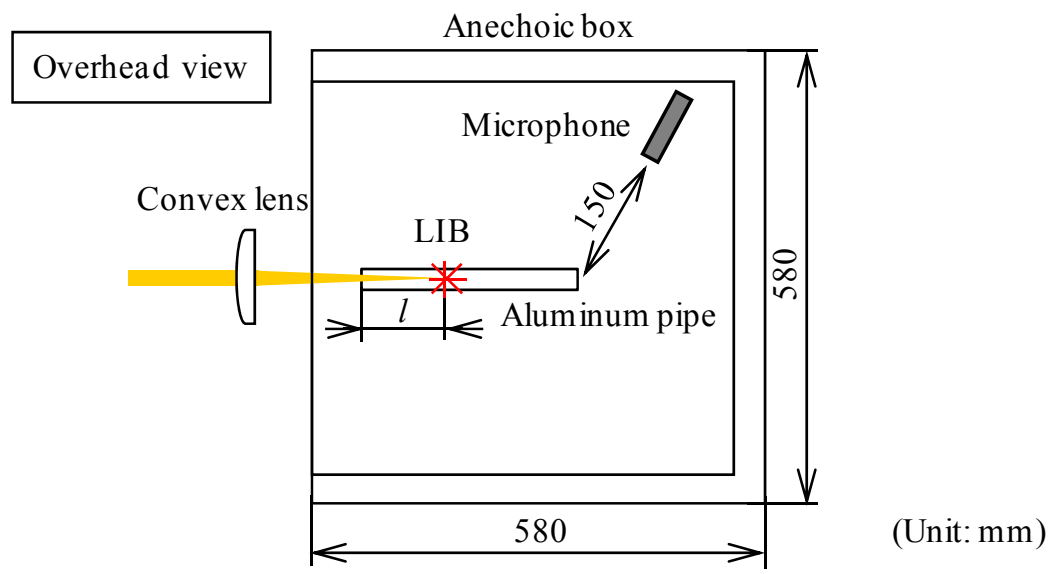

(b) Layout of microphone in the anechoic box

Fig. 11 Acoustic vibration testing system in a micro-space using a point source generated by LIB. 


\section{$5 \cdot 3$ 共鳴周波数の測定結果}

LIB による点音源でアルミニウムパイプ内を加振した際の時刻歴波形を図 12 に示寸. 図 12 より，30 ms 程度 の残響音が確認できる. 図 13 は，図 12 に対応するパワースペクトルを示している. 図 13 では, 2 種類の加振位 置でのパワースペクトル，および暗騒音を重ねて示している. 図 13 より, Point 1 では，4 次モードが消滅しそれ 以外のモードが卓越していることから，4 次モードの節を LIB による点音源で音響加振できているといえる．ま た, Point 2 では $5 \mathrm{kHz}$ 以下の全てのモードが励起されていることがわかる. $100 \mathrm{~Hz}$ 付近に観察されるピークは, 暗騒音による影響と考えられる．表 4 に，本手法，および式(3)の理論值から得られたアルミニウムパイプの共鳴 周波数を示す. 表 4 より，理論值と実験值の誤差は最大で $1.2 \%$ 程度であることから，LIBにより生成された点音 源を用いることで共鳴周波数が測定できることがわかった.

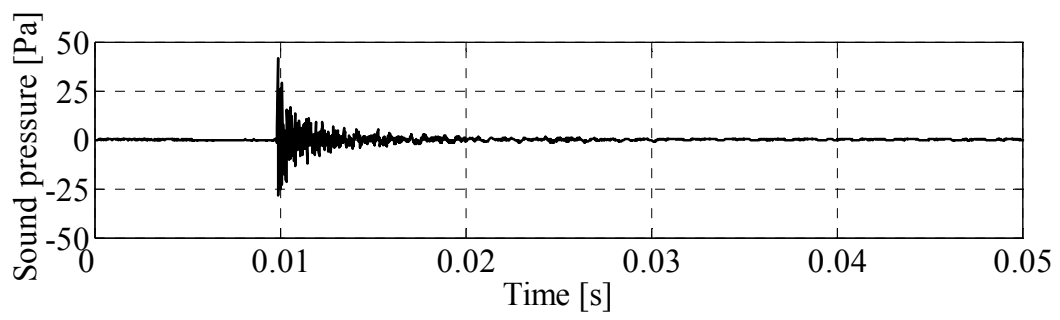

(a) Excitation point 1

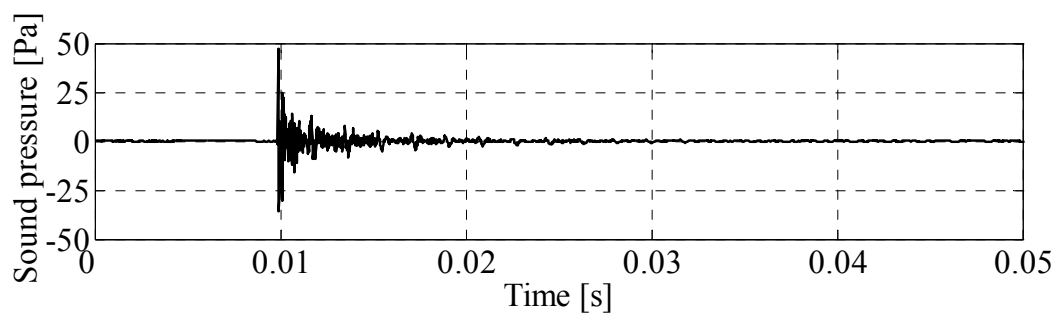

(b) Excitation point 2

Fig. 12 Time response of sound pressure generated by LIB.

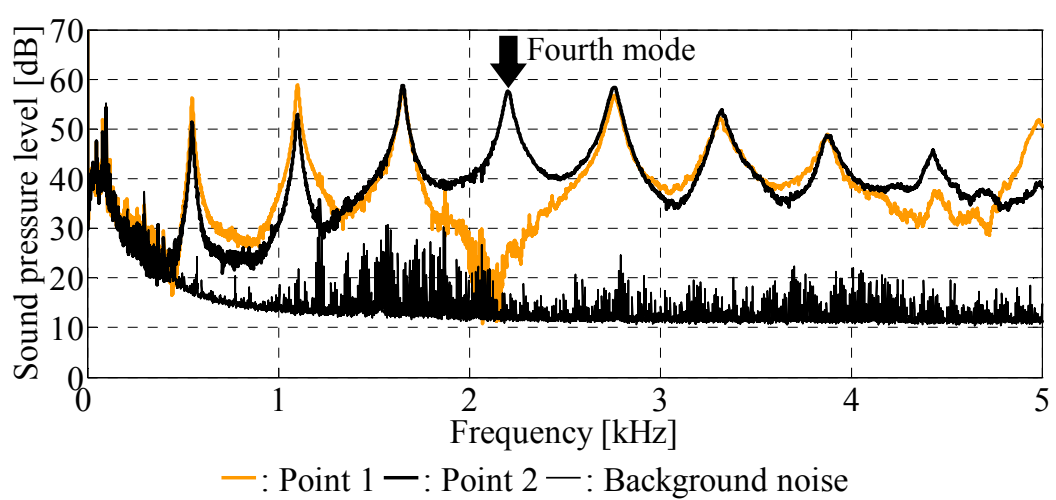

Fig. 13 Spectra of sound pressure level obtained by LIB excited at point 1 (nodal point of fourth mode (orange line) ), point 2 (black line) and measured background noise (thin black line). 
Table 4 Comparison of frequencies by theoretical and measurements

\begin{tabular}{|c|c|c|c|c|c|}
\hline \multirow[t]{2}{*}{ Mode } & \multirow[t]{2}{*}{ Theoretical [Hz] } & \multicolumn{2}{|c|}{$\begin{array}{c}\text { Point } 1 \\
\text { (Nodal point of fourth mode) }\end{array}$} & \multicolumn{2}{|l|}{ Point 2} \\
\hline & & Experimental $[\mathrm{Hz}]$ & Error [\%] & Experimental $[\mathrm{Hz}]$ & Error $[\%]$ \\
\hline $1 \mathrm{st}$ & 555 & 557 & 0.4 & 548 & 1.2 \\
\hline 2 nd & 1110 & 1101 & 0.8 & 1100 & 0.9 \\
\hline $3 \mathrm{rd}$ & 1664 & 1660 & 0.3 & 1662 & 0.1 \\
\hline 4th & 2219 & - & - & 2206 & 0.6 \\
\hline 5 th & 2774 & 2787 & 0.5 & 2780 & 0.2 \\
\hline 6th & 3329 & 3313 & 0.5 & 3333 & 0.1 \\
\hline 7th & 3884 & 3873 & 0.3 & 3873 & 0.3 \\
\hline 8th & 4438 & 4451 & 0.3 & 4428 & 0.2 \\
\hline 9th & 4993 & 4980 & 0.3 & 4989 & 0.1 \\
\hline
\end{tabular}

\section{6. 結 論}

本論文では，LIBにより生成された点音源に基づく音響加振法について検討し，以下の結論を得た.

（1）高出力 Nd: YAG パルスレーザーにより LIB を発生させ，これにより生成された理想的な点音源を用いた 音響加振システムを開発した．レーザービームのエネルギー密度をLIB の閾值に到達させ，これを $\mu \mathrm{m} 才$ ーダーの微小領域で生成するため, レーザービームを凸レンズにより集光する手法を導入した.

（2） LIB による点音源は，無指向性かつ理想的なインパルス波形であり，音響加振源としては数百 $\mathrm{kHz}$ 程度 の高周波数帯域までの成分を含むことがわかった．また，LIBによる点音源の音圧の再現性を確保するた めには，レーザーパルスエネルギー，スポット半径，焦点深度を適切に設定する必要があることを明ら かにした.

（3）アルミニウムパイプ内を微小空間と想定し，LIB により生成された点音源を用いて共鳴周波数を測定し た. 本手法, および理論的に得られた共鳴周波数を比較することで, 本手法の有効性を示した. 本手法 は，従来の音響加振法と比べ，スピーカの設置，配線が不要で音場に及ぼす影響がないため，微小空間 や密閉空間に対する音響加振を実現できる．また，任意のモードの節の位置をLIB による点音源で加振 したところ, 当該モードが励起されないことがわかった. これより, LIB による点音源を用いることで, 微小空間内の任意の位置を音響加振できることを示した.

\section{謝 辞}

本論文は, 日本学術振興会 科学研究費補助金 (若手研究(A), 課題番号 : 22686025 , および基盤研究(A), 課 題番号：22246027）の援助を受けて遂行した. ここに，深く感謝の意を表する.

\section{文献}

（1）山口俊昭, 吉村卓也, “振動音響連成系における実験モード解析に関する研究（音響加振装置の試作・評価と連成 系モードの同定)”, Dynamics and Design Conference (2010), CD-ROM (No.106).

(2) Kawahara, N., Beduneau, J. L., Nakayama, T., Tomita, E. and Ikeda, Y., "Spatially, temporally, and spectrally resolved measurement of laser-induced plasma in air”, Applied Physics B: Lasers and Optics, Vol.86 (2007), pp.605 - 614.

(3) Oksanen, M. and Hietanen, J. , "Photoacoustic breakdown sound source in air.", Ultrasonics Vol.32, No. 5 (1994), pp.327 -331 .

(4) Qin, Q. and Attenborough, K., "Characteristics and application of laser-generated acoustic shock waves in air." Applied Acoustics, Vol.65 (2004), pp.325 - 340. 
(5) 斎藤 剛, 古谷 博秀, 高橋 三能, “レーザブレークダウンを応用した最小点火エネルギー計測に対するレーザパル 又幅の影響”，日本機械学会論文集 B 編，Vol.73，No.727 (2007), pp.887-893.

(6) 堀 輝成, 赤松 史光, 芝原 正彦, “Nd: YAG レーザを用いたレーザ励起ブレイクダウン特性解析”, 高温学会誌, Vol.31, No.1 (2005), pp.19-25.

（7）土井元紀，大城理，千原大輔，杉浦忠男，河田聡，“レーザブレイクダウンによる球面超音波の発生と伝播の可視 化”，超音波エレクトロニクスの基礎と応用に関するシンポジウム講演予稿集 Vol.20 (1999), pp.89-90.

(8) 根本承次朗, “レーザ工学”, 培風館 (2001), pp.93-94.

（9）鈴木昭次，西村正治，雉本信哉，御法川学，“機械音響工学”，コロナ社 (2004), pp.40-41. 